\title{
Состав и функции сюжетов, основанных на якутских преданиях, в романе
} Далана «Сирота»

\author{
Маркова С.Г., студентка, \\ Северо-Восточный федеральный университет, \\ 2. Якутск \\ E-mail: sarqylana.m.93@mail.ru
}

Научный руководитель: д.филол.н., профессор Сивцева-Максимова П.В.

В.С. Яковлев-Далан (1928-1996) - народный писатель Республики Саха (Якутия) - является автором исторических романов «Сирота» (1983), «Тыгын Дархан» (1993).

Цель представленного исследования: сопоставительный анализ текстов исторических преданий с текстом романа Далана «Сирота», чтобы на примерах показать:

а. особый стиль эпического произведения «Сирота», созданного по типу приключенческого романа;

б. особенности использования в романе сюжетов народных преданий, которые имеют особую функцию в раскрытии главной идеи произведения.

В романе описывается жизнь народов, населяющих якутские земли, когда распри между племенами решались только вооруженными противостояниями междоусобных войн. Идея в том, что человек должен жить в гармонии с окружающим миром, и только тогда он может прийти к счастливой жизни.

В произведении XVI век предстает перед нами в той атмосфере, что царило пять столетий тому назад. Все это благодаря тому, что при работе над романом Далан основывался на работах якутских фольклористов (Сэсэн Боло, А.А. Саввин, А.С. Порядин, Н.Г. Березкин, Н.Т. Степанов и другие), и произведениях олонхосутов и певцов (Д.М. Говорова, С.А. Зверева и другие). Помимо этого, чтобы добиться правдивого описания прошлых лет, автор использует народные пословицы, поговорки, крылатые слова, афоризмы.

Роман «Сирота» имеет сложную, трехчастную сюжетную линию. Подобного рода сюжеты В.Е. Хализев относит к многолинейным сюжетам, “в которых одновременно, параллельно одна другой развертывается несколько событийных рядов, связанных с судьбой разных лиц и соприкасающихся лишь эпизодически” [Хализев: 234]. В произведении большое количество действующих лиц (более 100 персонажей). Упоминаются 13 племен, но действие в романе развивается вокруг племен Саха, Туматов и Тунгусов в лице главных героев Даганчи, Ньырбачан и Туођа Батыра. Все три сюжета переплетаются друг с другом в отдельных эпизодах.

В одном лишь сюжете о Ньырбачан насчитывается более 30-ти действующих лиц, из них, например, главная героиня Ньырбачан, Кэбээйи, Тыгын Дархан и т.д., реально существовавшие люди, о чем сидетельствуют материалы устного народного творчества. В картинах о Туоқа Батыре, встающей в параллель к двум остальным частям, тоже есть образы основанные на народных преданиях. Но только один из них, Даганча Батыр, действующее лицо. Остальные лишь упоминаются самим автором или в рассказах, диалогах героев (Хара Түмэн, Орхон Болодой и т.д.). 
В сюжете о Даганче персонажи с прототипами встречаются вовсе редко. При описании его жизни и характера Далан использовал легенды и предания о северных хосунах. Предания о хосунах составляют особую группу якутских преданий, где рассказ идет о воинах-мстителях. Такие старинные рассказы в основном имеют полноценную и устоявшуюся сюжетно-композиционную структуру.

В ходе исследования нами обнаружено 2 варианта преданий, близких по содержанию к роману, а именно к сюжету о Даганче: “Үрэн омук” и “Үнкээбил хосун». Содержания преданий аналогичны. Речь идет о кровной мести. В “Үнкээбил Хосун” человек по имени Манан Мэкчи убивает Үнкээбил хосуна. Забирает с собой всех его людей. Но он не догадывается о том, что мудрый старик, отец хосуна, спрятал своего внука. Впоследствии старик с внуком остаются одни. Время идет, мальчик подрастает. Когда ему исполняется 15 лет, юноша спрашивает о своих родителях. Старик ничего не скрывает, все ему объясняет, но не просит отмщения. Юноша не слушается его, идет мстить за своих родителей к Манан Мэкчи. Одерживает победу, берет в жены дочь врага и забирает все его богатство. Возвращается на родину к своему дедушке и живет счастливо и богато до самой смерти [6, стр. 109-110].

Большую часть сюжета предания Далан использует во вступительной части к роману, делая его отправной точкой в развитии сюжета произведения. Как мы ранее отмечали, в романе описываются три сюжета, тесно связанных друг с другом. В начале романа писатель во внимание читателя представляет Даганчу. В сюжете о юноше Далан вводит свои коррективы, дальше развивает сюжеты преданий, появляются новые образы, которых нет в преданиях. Например, если в преданиях старик не просит отмщения, то в романе, наоборот, Бакамда, дедушка Даганчи, готовит его к свершению мести.

Таким образом, сюжет преданий использован автором как «повествовательный ввод в Исходную ситуацию» [4, стр. 123], т.е. предстает в виде экспозиции. Далан объясняет причину зарождения мотива мести, которая является главной действующей силой в развитии двух сюжетов (Даганчи и Ньырбачан).

Помимо преданий автор широко использует этнографические материалы о северном народе - туматах. Например, по традициям племени тумат, перед первой важной схваткой хосуны туматов делали обряд кровопролития: Даганча сражается с бурым медведем; затем становление главным Хосуном с племени. Использование таких этнографических подробностей, дает роману реалистичность в описании быта и культуры в XVI веке.

A в сюжете о Ньырбачан, Далан использовал предания о предках Вилюйской группы улусов Республики Саха (Якутия). Люди называли их Ньырбаканами, и по старинным преданиям Ньырбачан является их прародительницей. Предания о Ньырбаканах впервые задокументировал И. Линденау. Так в книге Г.У. Эргис «Исторические предания и рассказы якутов» написано: «В рукописном фонде ИЯЛИ ЯФАН хранится 24 записи С.И. Боло, А.А. Саввина, В.И. Дмитриева и других о прародителях якутов Нюрбинского и Сунтарского районов» [6, стр. 297]. Сказания о судьбе Ньырбаканах весьма распространены в исторических преданиях. Фольклористы начали собирать устные рассказы о Ньырбачканах с 20-х годов. Одним из первых после Линденау рассказами о Ньырбаканах заинтересовался Г.В. Ксенофонтов. В 30-е годы к числу собирателей вошли С.И. Боло, А.А. Саввин, Г.Е. Федоров и др. Среди этих многочисленных исследователей Н.Т. Степанов рассмотрел сказания о Ньырбаканах 
более углубленно. Итогом его работ является книга «Ньырбачаан удьуордара», выпущенная в 1991.

В ходе работы нами обнаружено одиннадцать вариантов рассказов, относящихся к периоду жизни Ньырбачан до попадания её в долину Туймаада. В материалах Н.Т. Степанова путь Ньырбачаан описывается более детально, что отражается в сюжете эпизодов романа, например: упоминание о сорока ураса, воспоминания Ньырбачан о детстве с родителями [3, стр. 19]. Также подробно написано в книге Сэсэн Боло, в предании «Тонус тойоно Хоһуун уонна Дыгын Боотур» о брате Ньырбачан, который перед смертью сказал сестре как спастись ей от врагов [1, стр. 291].

Но все предания отличаются в деталях и сохраняют устоявщийся сюжет. Почти во всех говорится, что на Вилюйской земле жило некое племя. Однажды к ним с войной приходит другое племя. От этой бойни спасается один человек. Девушка Ньырбачан (в некоторых преданиях Ньырбакан, Дьаархан, старуха Дьаардаах). Она уплывает по реке Вилюю. Добирается до Лены и становится женой у Саха Уранхая, часто говорится, что она становится побочной женой отца Тыгына Дархана. Из вышесказанного можно сказать, что писатель использовал единый сюжет всех устных рассказов о Ньырбаканах. Но здесь нужно отметить и то, что в преданиях Вилюйских улусов помимо этих есть и другие. Например, сказания о хосунах, о Тыгыне Дархане итд.

В большинстве вариантов говорится, что племя Ньырбачан - тунгусы, и на них нападают туматы. Но в других преданиях она является туматкой, а нападают на них тунгусы или русские. Есть еще вариант, где написано о том, что на неё хотят напасть люди из своего племени.

В вариантах отличается возраст главной героини. Например, в преданиях Мархинского района девушке 12 лет, а в других она взрослая женщина. Но Далан остановился на возрасте - 10, что усугубляет и без того сложную ситуацию. Читателю остается лишь гадать, сможет ли она выжить, одна в суровой тайге, в столь юном возрасте. Но она умна не по годам, и ее силой воли, любовью к жизни можно лишь восторгаться. Она является одной из положительных персонажей, которая раскрыта более цельно чем остальные герои. В романе путь Ньырбачан описан очень увлекательно для читателя. Автор добавляет такие художественные эпизоды, как девочка спаслась от нападения рыси, убежала от преследования волка, добавлены ее наблюдения жизни других племен, которых она издалека замечает и прячется.

Далан при написании сюжета о Ньырбачан использует обширные данные из древних легенд в формах лаконичных сюжетов преданий. Он использовал образы, сюжеты преданий, но по своему творчески улучшил и мастерски переработал. Усилил психологические портреты исторических персонажей с помощью композиционных элементов и приемов, таких как сон персонажа, рассказ в рассказе, ретроспекция и т.д.

Таким образом в романе «Сирота» писатель полностью основывался на фольклорных сюжетах и этнографических материлах. Но не прямо повторил сюжет преданий, а творчески обработал, в контексте своего мировоззрения. Таким образом, Далан написал роман о жизни народов, населяющих земли Якутии в XVI веке и внёс свой бесценный вклад в развитие родной литературы. 


\title{
Список литература:
}

1. Дьячковскай Д.М. - Сэһэн Боло. ЛиэнэБэ нуучча кэлиэн иннинээБи саха оло5о: урукку Дьокуускай уокурук сахаларын былыргыттан кэпсээннэринэн. - Я.: Нац.кн. изд-во “Бичик”, 1994. - 352 с.

2. Петров В.Т. Фольклорные традиции в якутской советской литературе/В.Т. Петров. - М.: изд-во “Наука”, 1978. 258 с.

3. Степанов Н.Т. Ньырбакаан удьуордара. - Я.: ССРС НА СО Саха сиринээђи научнай киинэ, 1991. - 182 с.

4.Томашевский Б.В. Теория литературы. Поэтика: Учебн. пособие/Б.В. Томашевский. - М.: Аспект Пресс, 1999. - 334 с.

5. Хализев В.Е. Теория литературы: Учебник/В.Е. Хализев. - 4-е изд., испр. и доп. - М.: Высш. шк., 2004. - 405 с.

6. Эргис Г.У. Исторические предания и рассказы якутов. В двух частях, 1-я часть/Г.У. Эргис. - Москва - Ленинград: изд-во Академии наук СССР, 1960. - 324 с.

7. Яковлев В.С.-Далан. Глухой Вилюй/Худож. Шапошникова Т.Е. - Якутск: Нац. кн. изд-во “Бичик”, 1993. - 336 с.

\section{Традиция романтизма в прозе Н.С. Гумилева}

\author{
Мачаева С.М., студентка, \\ Технический институт (филиал) \\ Северо-Восточного федерального университета, \\ 2. Нерюнгри \\ E-mail: chokiwa80@gmail.com
}

Научный руководитель: стариий преподаватель Игонина С.В.

В литературоведении бытовало мнение о том, что «долгое время развитие его (Н.С. Гумилева) отличалось удивительной замедленностью и неоригинальностью» [1]. Этого утверждения было достаточно, чтобы объяснить особенную, мистическую поэтику Гумилева - акмеист, не сумевший отринуть символизм. Позже исследователи пришли к выводу, что Гумилев не символист, а поэт романтического толка, особенно сильно подверженный традициям романтизма в начале творческого пути. Поэтому основоположник акмеизма в литературоведении позиционируется как поэтконквистадор, поэт-воин, поэт-рыцарь. И присутствие романтических мотивов в творчестве Николая Гумилева, как и ряда других авторов, которых принято относить к акмеизму, сегодня ни у кого не вызывает сомнения и может быть описано ёмкой парадоксальной формулой: «Романтизм преодоленный, но непреодолимый» [2]. Однако романтизм Гумилева имеет свою специфику преодоления романтической традиции - на всех «пластах взаимодействия» и при реализации на всех уровнях художественного текста.

Предметом нашего исследования является литературная традиция романтизма в прозе Н. Гумилева. Исследование не представляется возможным без рассмотрения традиции как литературоведческой категории. В современном литературоведении термин «традиция» имеет слишком широкие теоретические обозначения. Наиболее 